inclosed slabs of ice, and torn them from the unfrozen and softer peat below. The slabs may be compared to sandwiches, the ice representing the meat. The ice is evidently fresh-water ice, and possesses a striated prismatic structure at right angles to its surface. In places it protrudes like a tongue from the peat, and is theis occasionally perforated with round holes evidently melted through it.

Is it not possible that some of the beds mentioned by geolo gists in Russia and North America, consisting of alternate layers of ice and earth or gravel, may have been formed similarly by percolation of water, and not be truly bedded, but intrusive?

Park Corner, Blundellsands, January 30

T. Mellard ReAde

P.S.-Since writing the above $I$ have again visited the shore to-day, but all the slabs have been rafted out to sea by the high tide. With my geological hammer I broke off some of the frozen peat in situ, and find the explanation given to be substantially correct; but I also found that the upper layer of peat was minutely and beantifully interlaminated with ice. It is quite evident that the ice is the frozen water which has percolated from the sand-hills.

January $3 \mathrm{I}$

\section{The Squirrel Crossing Water}

NEVER having heard of the squirrel taking to the water, I send the following anthentic communication. I had heard the story told by another person, and thinking it of sufficient interest I requested her to get it in detail from the lady under whose personal observation it had come. This the latter has most kindly complied with, and I forward it, trusting it may prove of interest to some of the readers of NATURE interested in the habits of animals. Loch Voil, in Perthshire, near Balquhidder, is about four miles in length, with a mean breadth of about one. third of a mile - a considerable extent of water for so small a rodent to face and cross, in search, I suppose, of new nutting grounds.

\section{Thalford House, near Guildford, February 5}

$$
\text { H. H. Godwin-Austen }
$$

"Mountquhanie, Cupar Fife

"When rowing two ladies down Loch Voil, one afternoon last August, I observed what looked like a little stripe of red brown fur in the middle of the loch. On coming nearer we saw that it was a squirel swimming across, its tail lying flat on the water. We then heard jts claws scratching on the side of the boat, and to our surprice the little bedraggled sprite appeared on the bow of the boat. It was evidently tired, for it sat quite still, staring at us and panting. I rowed on towards the shore, hoping to be able to ferry it across, but after a few minutes it scrambled down to the water again and resumed its journey, probably frightened at the sight of the collie dog who was in the boat. We watched it swimming till it looked like a small sjeck close to the shore, but lost sight of it before it landed."

Sea-waves. -E. B. P., I8, Cromwell Place, S.W., asks : Can any reader of NATURE inform me as to in what books or pamphlets I can obtain the best information relating to the height and length of sea-waves, especially when considered in relation to the navigation of vessels?

\section{BARON NORDENSKJÖLD IN FINLAND}

$A \mathrm{~S}$ is known, Baron Nordenskjöld was born in Finland, $\mathrm{A}$ and eompleted his studies at the University of Helsingfors. After his recent visit to St. Petersburg, where the celebrated explorer was made much of, he promised to stop at Helsingfors a few days, for the first time after his successful discovery of the North-East Passage and his circumnavigation of the Eurasian Continent. Having previously paid a short visit to his paternal hall (Frugärd), N ordenskjöld, accompanied by the Baroness his wife, arrived at Helsingfors on the evening of January 13 . He was received at the railway station by a deputation consisting of the Rector of the University, Mr. H. Lagus; the

\footnotetext{
1 From a Helsingfors Correspondent.
}

President of the Finnish Society of Science, Mr. G. Mittag-Leffler; the Secretary, Mr. L. L. Lindelöf, and others, as well as a select chorus of students, who sang a few patriotic songs. Before the station-house a crowd numbering thousands of people stood cheering and greeting him.

On January 14 the Society of Science had arranged a special meeting, to which friends and followers of science had been invited, and at which were present members of Government, professors of the University, a few of the higher military dignitaries, and a great many fashionables of the town, ladies as well as gentlemen. After an interesting lecture "On the Religions of the Populations of Siberia" by the linguist, Prof. A. Ahlquist, the President of the Society of Science, Mr. Mittag-Leffler, presented to Baron Nordenskjöld a gold medal struck by order of the Society of Science, in memory of their renowned countryman and honorary member, and of the remarkable historical event. The presentation of the medal was accompanied by an address, in which it was stated that the Society of Science, being neither wealthy nor numerous, and well remembering to what a little nation it belonged, could not and would not try to compete with the many eminent scientific societies which had already honoured him with their grants and gifts. Yet the Society of Science hoped Baron Nordenskjöld would kindlyaccept this tribute of admiration, as having issued from his native country. Nordenskjöld expressed his gratitude in a hearty manner, and then gave a lecture on his "Observations of the Northern Lights at Behring Strait," which greatly excited the interest of his audience. Nordenskjöld was then entertained at dinner by the Scientific Society and the University, at which entertainment toasts were given in honour of Baron Nordenskjöld, the Baroness, and the members of the Vega Expedition. At the close of the dinner a torchlight procession, arranged by students, appeared, paying homage to their celebrated countryman by singing and cheering.

The Helsingfors Skating Club having meanwhile adorned its skating-rink on the ice with electric lights and innumerable lamps and torches, then had a visit from the Baron. He was received with singing by a student chorus, followed by the appearance of two polar bears with a chair on skates, who, giving him kind regards from Spitzbergen and Siberia, took him at a tremendous rate up to a pretty little ice temple, where he was greeted by twelve young ladies and gentlemen, all dressed in the picturesque costumes of the Chukchis. These gave him a hearty welcome, and then, with the bears, performed a characteristic dance on skates. Surrounded by thousands of cheering spectators, he was taken back to his carriage again by the bears. In expressing his gratitude Nordenskjöld said that if the Chukchis, and especially the ladies, had been so civilised he would most certainly not have left them so soon.

The following day he was invited to dinner by the Governor-General of Finland, Count Adlerberg, and in the evening the inhabitants of Helsingfors gave a splendid banquet, at which toasts were given in honour of the Emperor Alexander II. and King Oscar II., followed by a speech by Prof. L. L. Lindelöf, relating Baron Nord. enskjöld's great deed, and inviting the audience to drink to his health. Other toasts were also given in honour of the Baroness Nordenskjöld, the promoters and members of the Vega Expedition, the Fatherland, \&c. Nordenskjöld's appearance in Finland excited great rejoicing everywhere, but amid that rejoicing the melancholy thought occurred to one's mind that he had been denied the opportunity of living, and acting, and working in his own country.

On January 16 , early in the morning, he left Helsingfors; once more the singing of the students sounded on the platform amid loud cries of "Hurrah" from friends and admirers. 